\title{
STUDIES OF THE ANTIDIURESIS OF QUIET STANDING: OB- SERVATIONS UPON ELECTROLYTE AND ACID-BASE EXCRETION DURING SULFATE DIURESIS ${ }^{1}$
}

\author{
BY FRANKLIN H. EPSTEIN, CHARLES R. KLEEMAN, EZRA LAMDIN, AND \\ MILTON E. RUBINI
}

\author{
(From the Department of Internal Medicine, Yale University School of Medicine, New Haven, \\ Conn.)
}

(Submitted for publication September 12, 1955; accepted November 28, 1955)

It is well established that when blood is pooled in the limbs, either by the use of congesting tourniquets or by standing erect and motionless, there is an immediate and marked decrease in urinary flow and in the excretion of sodium and chloride $(1,2)$. This is usually accompanied by a slight diminution in glomerular filtration rate and by little or no change in the excretion of potassium and ammonium or in urinary $\mathrm{pH}(2-4)$. The mechanisms by which sodium excretion is diminished remain unclear, although considerable evidence suggests that the rates of urinary excretion of sodium and other strong electrolytes are interrelated through a process of ionic exchange in the renal tubules (5). It was thought that these relationships might be illuminated by measuring changes in the excretion of $\mathrm{K}^{+}$and $\mathrm{H}^{+}$, when reabsorption of $\mathrm{Na}^{+}$was acutely increased but total cation reabsorption limited, by assuming the upright posture during the course of a sodium sulfate diuresis.

\section{METHODS}

Experiments were carried out on normal young men, in the morning after a light breakfast. An isotonic solution of sodium sulfate $(248 \mathrm{mEq}$. per L., $296 \mathrm{mOsm}$. per L.) 2 was infused intravenously at 4 to $5 \mathrm{cc}$. per $\mathrm{min}$. over a period of six hours in all experiments. Four kinds of experiments were performed. In Group I (control) the subject remained supine for the duration of the procedure. In Group II he stood upright and motionless during the fifth hour of the infusion. In Groups III and IV the latter procedure was repeated while an effort was

1 Aided by Grants from the U. S. Public Health Service (H834) and the Department of the Army (DA-49007-MD-116).

2 Seventeen and one-half $\mathrm{gm}$. of $\mathrm{Na}_{2} \mathrm{SO}_{4}$ (anhydrous) were dissolved in $1,000 \mathrm{cc}$. of distilled water. This solution has the same freezing point as a solution of $\mathrm{NaCl}$ containing $148 \mathrm{mM}$. per kg., although it contains 248 mEq. per L. of $\mathrm{Na}_{2} \mathrm{SO}_{4}$. The osmotic coefficient of $\mathrm{Na}_{2} \mathrm{SO}_{4}$ in this range of concentration is 0.74 (6). made to alter renal tubular secretion with a carbonic anhydrase inhibitor (Diamox ${ }^{(B)}$ ) or an organic mercurial (Thiomerin(8). On three occasions (Group III) subjects ingested $500 \mathrm{mg}$. of Diamox at the start of the experiment and $250 \mathrm{mg}$. at the beginning of the fourth hour. In three subjects (Group IV) $1 \mathrm{cc}$. of Thiomerin was incorporated in each liter of the infusion and $2 \mathrm{cc}$. of Thiomerin were injected intramuscularly at the beginning of the second hour.

Samples of arterialized venous blood and of urine, voided under mineral oil, were collected every half-hour or hour. Serum and urine were analyzed for endogenous creatinine (7), sodium and potassium (8), chloride (9, 10) and carbon dioxide (11). Sulfate was determined by a turbidimetric technique (12) in the earlier experiments and later by a modified colorimetric method using benzidine $(13,14)$. $\mathrm{pH}$ of blood and urine was determined with a Cambridge $\mathrm{pH}$ meter. Urine was analyzed for ammonia (15) and in most cases for titratable acidity.

\section{RESULTS}

\section{Continuous infusion of sodium sulfate in the supine position (Table I, Figure 1)}

The rates of excretion of sodium and sulfate increased rapidly during the first three hours but continued to rise only very slowly during the fourth, fifth and sixth hours, as equilibrium between the intake and output of sulfate was approached. During the last three hours the clearance of sulfate progressively approached the clearance of endogenous creatinine. Although the excretion of potassium invariably increased from the first to the second hour, this was not true of ammonium, and during the final three hours the excretion of $\mathrm{K}^{+}$and $\mathrm{NH}_{4}^{+}$was fairly constant. The excretion of chloride at first increased slightly but then progressively declined to very low levels. The normal diurnal variation in urinary $\mathrm{pH}$ was unaltered. Urinary flow and the clearance of endogenous creatinine changed little during the six hours of infusion. 
TABLE I

Urinary constituents during the fourth, fifth and sixth hours of a control infusion of isotonic sodium sulfate in supine subjects

\begin{tabular}{|c|c|c|c|c|c|c|c|c|c|c|}
\hline \multirow[b]{2}{*}{ Subject } & \multirow{2}{*}{$\begin{array}{l}\text { Hours } \\
\text { after } \\
\text { start of } \\
\text { infusion }\end{array}$} & \multirow[b]{2}{*}{ Posture } & \multicolumn{8}{|c|}{ Urine } \\
\hline & & & Flow & $\mathrm{Na}^{+}$ & $\mathrm{K}^{+}$ & $\mathrm{NH}_{4}{ }^{+}$ & $\mathrm{pH}$ & $\mathrm{Cl}^{-}$ & $\mathrm{SO}_{4}^{-}$ & $\mathrm{C}_{\text {or }}$ \\
\hline F. E. & $\begin{array}{l}4 \\
5 \\
6\end{array}$ & $\begin{array}{l}\text { Supine } \\
\text { Supine } \\
\text { Supine }\end{array}$ & $\begin{array}{c}c c . / \min . \\
3.61 \\
3.28 \\
3.32\end{array}$ & $\begin{array}{r}\mu E q . / \\
\text { min. } \\
940 \\
948 \\
1,050\end{array}$ & $\begin{array}{l}\mu E q . / \\
\text { min. } \\
123 \\
122 \\
113\end{array}$ & $\begin{array}{c}\mu E q . / \\
\min . \\
24 \\
27 \\
26\end{array}$ & $\begin{array}{l}6.70 \\
6.19 \\
6.20\end{array}$ & $\begin{array}{c}\mu E q . / \\
\min . \\
67 \\
29 \\
34\end{array}$ & $\begin{array}{c}\mu E q . / \\
\text { min. } \\
1,162 \\
1,185 \\
1,280\end{array}$ & $\begin{array}{c}c c . / \min \\
128 \\
123 \\
130\end{array}$ \\
\hline E. L. & $\begin{array}{l}4 \\
5 \\
6\end{array}$ & $\begin{array}{l}\text { Supine } \\
\text { Supine } \\
\text { Supine }\end{array}$ & $\begin{array}{l}2.02 \\
2.02 \\
2.05\end{array}$ & $\begin{array}{l}728 \\
780 \\
830\end{array}$ & $\begin{array}{l}150 \\
134 \\
105\end{array}$ & $\begin{array}{l}42 \\
42 \\
38\end{array}$ & $\begin{array}{l}5.48 \\
5.08 \\
5.22\end{array}$ & $\begin{array}{l}32 \\
21 \\
18\end{array}$ & $\begin{array}{l}895 \\
921 \\
950\end{array}$ & $\begin{array}{l}140 \\
146 \\
142\end{array}$ \\
\hline M. R. & $\begin{array}{l}4 \\
5 \\
6\end{array}$ & $\begin{array}{l}\text { Supine } \\
\text { Supine } \\
\text { Supine }\end{array}$ & $\begin{array}{l}4.88 \\
4.92 \\
5.00\end{array}$ & $\begin{array}{r}895 \\
1,025 \\
1,180\end{array}$ & $\begin{array}{l}85 \\
74 \\
55\end{array}$ & $\begin{array}{l}40 \\
36 \\
35\end{array}$ & $\begin{array}{l}5.08 \\
5.42 \\
6.00\end{array}$ & $\begin{array}{r}51 \\
71 \\
105\end{array}$ & $\begin{array}{l}1,010 \\
1,120 \\
1,232\end{array}$ & $\begin{array}{l}132 \\
139 \\
140\end{array}$ \\
\hline C. $\mathrm{K}$. & $\begin{array}{l}4 \\
5 \\
6\end{array}$ & $\begin{array}{l}\text { Supine } \\
\text { Supine } \\
\text { Supine }\end{array}$ & $\begin{array}{l}2.62 \\
2.21 \\
2.42\end{array}$ & $\begin{array}{l}861 \\
818 \\
957\end{array}$ & $\begin{array}{r}111 \\
101 \\
88\end{array}$ & $\begin{array}{l}23 \\
28 \\
34\end{array}$ & $\begin{array}{l}6.63 \\
5.58 \\
5.00\end{array}$ & $\begin{array}{l}58 \\
22 \\
15\end{array}$ & $\begin{array}{r}955 \\
944 \\
1,093\end{array}$ & $\begin{array}{l}121 \\
115 \\
126\end{array}$ \\
\hline D. W. & $\begin{array}{l}4 \\
5 \\
6\end{array}$ & $\begin{array}{l}\text { Supine } \\
\text { Supine } \\
\text { Supine }\end{array}$ & $\begin{array}{l}3.92 \\
4.13 \\
3.94\end{array}$ & $\begin{array}{l}1,160 \\
1,165 \\
1,230\end{array}$ & $\begin{array}{r}121 \\
103 \\
96\end{array}$ & $\begin{array}{l}28 \\
25 \\
23\end{array}$ & $\begin{array}{l}6.65 \\
6.50 \\
6.65\end{array}$ & $\begin{array}{l}98 \\
76 \\
58\end{array}$ & $\begin{array}{l}1,304 \\
1,258 \\
1,342\end{array}$ & $\begin{array}{l}120 \\
113 \\
110\end{array}$ \\
\hline Mean & $\begin{array}{l}4 \\
5 \\
6\end{array}$ & . & $\begin{array}{l}3.41 \\
3.31 \\
3.35\end{array}$ & $\begin{array}{r}917 \\
947 \\
1,049\end{array}$ & $\begin{array}{r}118 \\
107 \\
91\end{array}$ & $\begin{array}{l}31 \\
31 \\
31\end{array}$ & $\begin{array}{l}6.11 \\
5.76 \\
5.61\end{array}$ & $\begin{array}{l}61 \\
44 \\
46\end{array}$ & $\begin{array}{l}1,065 \\
1,085 \\
1,179\end{array}$ & $\begin{array}{l}128 \\
127 \\
127\end{array}$ \\
\hline
\end{tabular}

II. Effects of motionless standing during the fifth hour of a sodium sulfate infusion (Table II, Figure 2)

Standing caused a decrease in the excretion of sodium in each of five subjects and produced a urine almost free of chloride, while sulfate excretion remained essentially unchanged. The excretion of both potassium and ammonium, on the other hand, increased in the erect posture and usually diminished when the subject lay down again. There was an abrupt decrease in urinary $\mathrm{pH}$, and values as low as 4.27 (uncorrected for the difference between room and body temperature) were recorded during or shortly after the period of standing. These striking increases in the acidity of the urine were not preceded or accompanied by changes in the $\mathrm{pH}$ of arterialized blood or in serum bicarbonate. Endogenous creatinine clearances increased slightly in one subject and fell an average of $11 \mathrm{cc}$. per min. in four others. Sustained by the continued excretion of sulfate, the flow of urine diminished only slightly during the stimulus of quiet standing.

Experienced subjects reported that while standing erect during sulfate infusions symptoms of faintness, giddiness and nausea appeared earlier and more regularly than during prolonged quiet standing without sulfate. These symptoms were even more pronounced in the experiments of Groups III and IV, and always disappeared promptly when the subject lay down. III. Effect of a carbonic anhydrase inhibitor
(Table III)

In three men to whom Diamox had been administered, quiet standing during the fifth hour

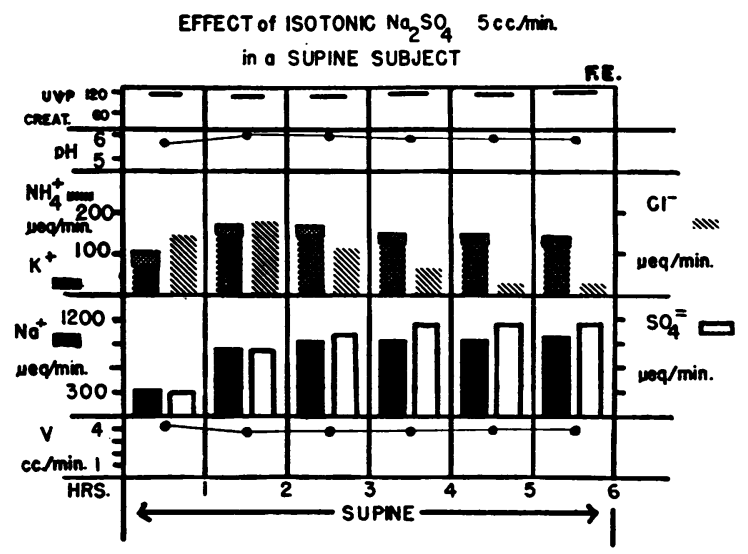

Figure 1 
TABLE II

Effects of the erect posture upon electrolyte excretion during an infusion of sodium sulfate

\begin{tabular}{|c|c|c|c|c|c|c|c|c|c|c|}
\hline \multirow[b]{2}{*}{ Subject } & \multirow{2}{*}{$\begin{array}{l}\text { Hours } \\
\text { after } \\
\text { start of } \\
\text { infusion }\end{array}$} & \multirow[b]{2}{*}{ Posture } & \multicolumn{8}{|c|}{ Urine } \\
\hline & & & Flow & $\mathrm{Na}^{+}$ & $\mathbf{K}^{+}$ & $\mathrm{NH}_{4}{ }^{+}$ & $\mathrm{pH}$ & $\mathrm{Cl}^{-}$ & $\mathrm{SO}_{4}^{-}$ & $C_{r o r}$ \\
\hline F. E. & $\begin{array}{l}4 \\
5 \\
6\end{array}$ & $\begin{array}{l}\text { Supine } \\
\text { Standing } \\
\text { Supine }\end{array}$ & $\begin{array}{c}c c . / \min . \\
3.40 \\
2.47 \\
2.12\end{array}$ & $\begin{array}{c}\mu E q . / \\
\text { min. } \\
843 \\
741 \\
666\end{array}$ & $\begin{array}{c}\mu E q . / \\
\min . \\
137 \\
228 \\
180\end{array}$ & $\begin{array}{c}\mu E q . / \\
\text { min. } \\
31 \\
38 \\
30\end{array}$ & $\begin{array}{l}5.62 \\
4.33 \\
4.83\end{array}$ & $\begin{array}{r}\mu E q . / \\
\min . \\
15 \\
4 \\
3\end{array}$ & $\begin{array}{c}\mu E q . / \\
\text { min. } \\
1,023 \\
1,025 \\
911\end{array}$ & $\begin{array}{c}c . / \min . \\
118 \\
112 \\
101\end{array}$ \\
\hline E. L. & $\begin{array}{l}4 \\
5 \\
6\end{array}$ & $\begin{array}{l}\text { Supine } \\
\text { Standing } \\
\text { Supine }\end{array}$ & $\begin{array}{l}2.41 \\
2.04 \\
2.09\end{array}$ & $\begin{array}{l}773 \\
745 \\
764\end{array}$ & $\begin{array}{l}145 \\
176 \\
162\end{array}$ & $\begin{array}{l}44 \\
56 \\
49\end{array}$ & $\begin{array}{l}6.38 \\
4.67 \\
5.10\end{array}$ & $\begin{array}{r}69 \\
18 \\
9\end{array}$ & $\begin{array}{l}874 \\
966 \\
987\end{array}$ & $\begin{array}{l}143 \\
146 \\
149\end{array}$ \\
\hline M. R. & $\begin{array}{l}4 \\
5 \\
6\end{array}$ & $\begin{array}{l}\text { Supine } \\
\text { Standing } \\
\text { Supine }\end{array}$ & $\begin{array}{l}2.66 \\
2.02 \\
2.71\end{array}$ & $\begin{array}{r}1,039 \\
853 \\
989\end{array}$ & $\begin{array}{r}60 \\
84 \\
101\end{array}$ & $\begin{array}{l}40 \\
50 \\
54\end{array}$ & $\begin{array}{l}4.80 \\
4.27 \\
4.32\end{array}$ & $\begin{array}{r}33 \\
11 \\
4\end{array}$ & $\begin{array}{l}1,160 \\
1,023 \\
1,188\end{array}$ & $\begin{array}{r}125 \\
99 \\
120\end{array}$ \\
\hline C. $\mathbf{K}$. & $\begin{array}{l}4 \\
5 \\
6\end{array}$ & $\begin{array}{l}\text { Supine } \\
\text { Standing } \\
\text { Supine }\end{array}$ & $\begin{array}{l}3.71 \\
2.30 \\
2.27\end{array}$ & $\begin{array}{r}1,130 \\
896 \\
994\end{array}$ & $\begin{array}{r}117 \\
127 \\
88\end{array}$ & $\begin{array}{l}18 \\
39 \\
38\end{array}$ & $\begin{array}{l}6.96 \\
4.85 \\
4.82\end{array}$ & $\begin{array}{r}151 \\
25 \\
9\end{array}$ & $\begin{array}{l}1,223 \\
1,131 \\
1,223\end{array}$ & $\begin{array}{l}147 \\
144 \\
144\end{array}$ \\
\hline D. W. & $\begin{array}{l}4 \\
5 \\
6\end{array}$ & $\begin{array}{l}\text { Supine } \\
\text { Standing } \\
\text { Supine }\end{array}$ & $\begin{array}{l}3.20 \\
2.52 \\
2.67\end{array}$ & $\begin{array}{r}1,025 \\
923 \\
1,066\end{array}$ & $\begin{array}{l}152 \\
188 \\
169\end{array}$ & $\begin{array}{l}27 \\
37 \\
33\end{array}$ & $\begin{array}{l}6.44 \\
4.85 \\
4.99\end{array}$ & $\begin{array}{l}33 \\
17 \\
15\end{array}$ & $\begin{array}{l}1,242 \\
1,250 \\
1,326\end{array}$ & $\begin{array}{l}111 \\
100 \\
112\end{array}$ \\
\hline Mean & $\begin{array}{l}4 \\
5 \\
6\end{array}$ & $\begin{array}{l}\text { Supine } \\
\text { Standing } \\
\text { Supine }\end{array}$ & $\begin{array}{l}3.08 \\
2.27 \\
2.37\end{array}$ & $\begin{array}{l}962 \\
832 \\
896\end{array}$ & $\begin{array}{l}122 \\
161 \\
140\end{array}$ & $\begin{array}{l}32 \\
44 \\
41\end{array}$ & $\begin{array}{l}6.04 \\
4.59 \\
4.81\end{array}$ & $\begin{array}{r}60 \\
13 \\
8\end{array}$ & $\begin{array}{l}1,104 \\
1,079 \\
1,127\end{array}$ & $\begin{array}{l}129 \\
121 \\
125\end{array}$ \\
\hline
\end{tabular}

of a sulfate infusion was accompanied by a decreased excretion of sodium, chloride, bicarbonate and endogenous creatinine. In contrast to the preceding experiments, however, urinary $p H$ and the excretion of ammonium did not change appreciably. The excretion of potassium, already at a high level, did not increase further when the subject stood up.

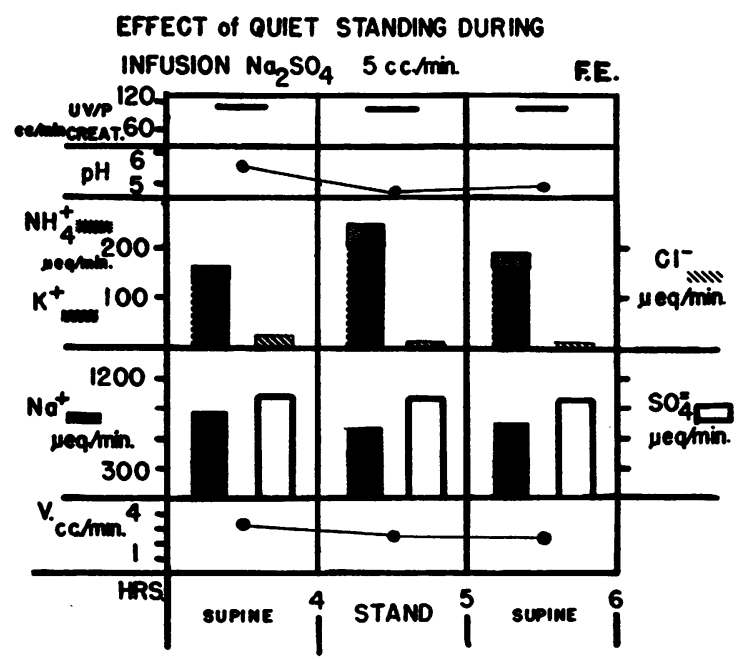

FIGURE 2
IV. Effect of an organic mercurial (Table IV)

In three subjects receiving Thiomerin the retention of sodium which accompanied motionless standing was not associated with an increased excretion of potassium. However, as in Group II, urinary $\mathrm{pH}$ became more acid and the excretion of ammonium increased.

Infusion of sodium sulfate, which normally diminishes the excretion of chloride (Group $I$ ), did not prevent the chloruretic effect of mercury in these experiments. Chloride excretion was therefore high throughout the procedure, although it fell in each case during the period of quiet standing.

\section{DISCUSSION}

The present experiments demonstrate once again that changing from the supine to the standing posture provides a specific stimulus to the renal tubular reabsorption of the sodium ion. The consequent retention of sodium is not accompanied by an increase in the rates of excretion of potassium and ammonium when quiet standing is superimposed upon a diuresis induced by water ingestion $(16,17)$, infusion of physiological saline $(4,17)$, 
EFFECT OF NA ${ }^{+}$RETENTION ON $\mathrm{K}^{+}$AND $\mathrm{H}^{+}$EXCRETION

TABLE III

Modification by Diamoxe of the response to quiet standing during an infusion of sodium sulfate

\begin{tabular}{|c|c|c|c|c|c|c|c|c|c|c|c|}
\hline \multirow[b]{2}{*}{ Subject } & \multirow{2}{*}{$\begin{array}{c}\text { Hours } \\
\text { after } \\
\text { start of } \\
\text { infusion }\end{array}$} & \multirow[b]{2}{*}{ Posture } & \multicolumn{9}{|c|}{ Urine } \\
\hline & & & Flow & $\mathrm{Na}^{+}$ & $\mathbf{K}^{+}$ & $\mathrm{NH}_{4}{ }^{+}$ & $\mathrm{pH}$ & $\mathrm{HCO}_{3}^{-}$ & $\mathrm{Cl}^{-}$ & so:- & $C_{e}$ \\
\hline E. L. & $\begin{array}{l}4 \\
5 \\
6\end{array}$ & $\begin{array}{l}\text { Supine } \\
\text { Standing } \\
\text { Supine }\end{array}$ & $\begin{array}{c}c c . / \min . \\
6.04 \\
3.97 \\
3.98\end{array}$ & $\begin{array}{c}\mu E q . l \\
\text { min. } \\
1,165 \\
1,020 \\
1,163\end{array}$ & $\begin{array}{c}\mu E_{q . /} \\
\min . \\
211 \\
201 \\
184\end{array}$ & $\begin{array}{c}\mu E_{q .} / \\
\min . \\
17.1 \\
17.5 \\
17.6\end{array}$ & $\begin{array}{l}7.57 \\
7.50 \\
7.41\end{array}$ & $\begin{array}{c}\boldsymbol{\mu} E q . / \\
\text { min. } \\
360 \\
210 \\
183\end{array}$ & $\begin{array}{c}\boldsymbol{E} Q . / \\
\text { min. } \\
78 \\
17 \\
20\end{array}$ & 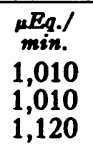 & $\begin{array}{c}c c . / m i x . \\
142 \\
135 \\
148\end{array}$ \\
\hline F. E. & $\begin{array}{l}4 \\
5 \\
6\end{array}$ & $\begin{array}{l}\text { Supine } \\
\text { Standing } \\
\text { Supine }\end{array}$ & $\begin{array}{l}6.20 \\
2.50 \\
3.29\end{array}$ & $\begin{array}{r}1,416 \\
740 \\
1,055\end{array}$ & $\begin{array}{l}224 \\
227 \\
200\end{array}$ & $\begin{array}{l}10.8 \\
10.8 \\
10.0\end{array}$ & $\begin{array}{l}7.54 \\
7.07 \\
7.20\end{array}$ & $\begin{array}{r}381 \\
62 \\
95\end{array}$ & $\begin{array}{r}125 \\
20 \\
10\end{array}$ & $\begin{array}{r}1,080 \\
850 \\
1,130\end{array}$ & $\begin{array}{r}110 \\
89 \\
99\end{array}$ \\
\hline M. E. & $\begin{array}{l}4 \\
4 \frac{1}{2} \\
5 \\
6\end{array}$ & $\begin{array}{l}\text { Supine } \\
\text { Standing } \\
\text { Standing } \\
\text { Supine }\end{array}$ & $\begin{array}{l}5.50 \\
3.63 \\
2.11 \\
3.33\end{array}$ & $\begin{array}{r}1,190 \\
970 \\
680 \\
1,230\end{array}$ & $\begin{array}{l}221 \\
220 \\
174 \\
211\end{array}$ & $\begin{array}{l}6.6 \\
5.2 \\
3.6 \\
6.3\end{array}$ & $\begin{array}{l}7.63 \\
7.56 \\
7.44 \\
7.43\end{array}$ & $\begin{array}{l}355 \\
262 \\
110 \\
180\end{array}$ & $\begin{array}{r}134 \\
78 \\
33 \\
30\end{array}$ & $\begin{array}{r}852 \\
855 \\
655 \\
1,110\end{array}$ & $\begin{array}{r}122 \\
122 \\
87 \\
148\end{array}$ \\
\hline
\end{tabular}

or infusions of mannitol, sodium bicarbonate or sodium phosphate (4). The fact that urinary outputs of potassium, ammonium and hydrogen ions were simultaneously increased when sodium retention was provoked during the infusion of a nonreabsorbable anion suggests alterations in tubular activity since this cannot be explained by the hypothesis of a lowered rate of glomerular filtration in the presence of unchanged tubular reabsorption. Furthermore, changes in glomerular filtration as indicated by clearances of endogenous creatinine were frequently small or absent in these experiments. However, the data do not permit a final decision as to whether changes in tubular activity might not possibly have been a by-product of lowered glomerular filtration, as Lauson and Thompson demonstrated in dogs whose renal artery was compressed (18).
In view of current theories of urinary acidification which postulate an inverse relationship between the rates of secretion of potassium and hydrogen ions (19), it is of interest that increases in the production of ammonium and marked falls in urinary $\mathrm{pH}$ were promoted acutely by quiet standing with a simultaneous increase in the excretion of potassium. Moreover, abrupt and intense acidification of the urine was produced without systemic acidosis. Analogous findings have been reported by Lauson and Thompson in dogs (18), by Schwartz, Jenson, and Relman in human subjects depleted of sodium or given adrenal steroids (20), and by other investigators who have given large loads of non-reabsorbable anions to patients with a tendency to retain sodium $(21,22)$.

The increased excretion of potassium and acid during the period of quiet standing must have been

TABLE IV

Modification by mercury of the response to quiet standing during an infusion of sodium sulfate

\begin{tabular}{|c|c|c|c|c|c|c|c|c|c|c|c|c|}
\hline \multirow[b]{2}{*}{ Subject } & \multirow{2}{*}{$\begin{array}{l}\text { Hours } \\
\text { after } \\
\text { start of } \\
\text { infusion }\end{array}$} & \multirow[b]{2}{*}{ Posture } & \multicolumn{10}{|c|}{ Urine } \\
\hline & & & Flow & $\mathrm{Na}^{+}$ & $\mathbf{K}^{+}$ & $\mathrm{NH}_{4}{ }^{+}$ & $\begin{array}{c}\text { Titr. } \\
\text { acidity }\end{array}$ & pH & $\mathrm{Cl}^{-}$ & $\mathrm{SO}_{4}^{-}$ & $\mathrm{HCO}_{3}^{-}$ & $C_{o r}$ \\
\hline C. $\mathrm{K}$. & $\begin{array}{l}4 \\
5 \\
6\end{array}$ & $\begin{array}{l}\text { Supine } \\
\text { Standing } \\
\text { Supine }\end{array}$ & $\begin{array}{c}c c . / \min . \\
4.22 \\
3.84 \\
10.0\end{array}$ & $\begin{array}{c}\mu E q . / \\
\text { min. } \\
1,238 \\
1,080 \\
2,215\end{array}$ & $\begin{array}{c}\mu E q . / \\
\min . \\
60 \\
64 \\
61\end{array}$ & $\begin{array}{c}\mu E q . / \\
\min . \\
22 \\
32 \\
28\end{array}$ & $\begin{array}{c}\mu E q . / \\
\text { min. } \\
1.6 \\
9.5 \\
2.4\end{array}$ & $\begin{array}{l}6.68 \\
5.40 \\
6.23\end{array}$ & $\begin{array}{c}\mu E q . / \\
\text { min. } \\
365 \\
305 \\
1,030\end{array}$ & $\begin{array}{c}\mu E q . / \\
\text { min. } \\
865 \\
864 \\
1,125\end{array}$ & $\begin{array}{c}\mu E q . / \\
\min . \\
33 \\
0 \\
34\end{array}$ & $\begin{array}{c}c c . / m i n . \\
92 \\
77 \\
93\end{array}$ \\
\hline E. L. & $\begin{array}{l}4 \\
5 \\
6\end{array}$ & $\begin{array}{l}\text { Supine } \\
\text { Standing } \\
\text { Supine }\end{array}$ & $\begin{array}{l}6.50 \\
6.40 \\
6.40\end{array}$ & $\begin{array}{l}2,240 \\
1,315 \\
1,974\end{array}$ & $\begin{array}{l}137 \\
132 \\
178\end{array}$ & $\begin{array}{l}41 \\
48 \\
38\end{array}$ & $\begin{array}{r}1.0 \\
12.5 \\
1.0\end{array}$ & $\begin{array}{l}6.75 \\
5.94 \\
6.70\end{array}$ & $\begin{array}{r}1,422 \\
530 \\
947\end{array}$ & $\begin{array}{r}985 \\
950 \\
1,150\end{array}$ & & $\begin{array}{r}92 \\
91 \\
112\end{array}$ \\
\hline F. E. & $\begin{array}{l}4 \\
5 \\
6\end{array}$ & $\begin{array}{l}\text { Supine } \\
\text { Standing } \\
\text { Supine }\end{array}$ & $\begin{array}{l}5.52 \\
2.02 \\
8.35\end{array}$ & $\begin{array}{r}1,140 \\
520 \\
1,540\end{array}$ & $\begin{array}{l}143 \\
140 \\
163\end{array}$ & $\begin{array}{l}19 \\
32 \\
30\end{array}$ & $\begin{array}{r}3.0 \\
10.0 \\
8.8\end{array}$ & $\begin{array}{l}6.93 \\
4.72 \\
5.66\end{array}$ & $\begin{array}{r}249 \\
31 \\
745\end{array}$ & $\begin{array}{l}780 \\
475 \\
980\end{array}$ & $\begin{array}{r}54 \\
0 \\
0\end{array}$ & $\begin{array}{r}120 \\
67 \\
108\end{array}$ \\
\hline
\end{tabular}


secondary either to diminished tubular reabsorption or to increased tubular secretion of these substances. The results of the studies with Diamox ${ }^{\circledR}$ and mercury might be considered to favor the latter view. The dose of Diamox administered would be expected to inhibit tubular secretion of $\mathrm{H}^{+}$and to accelerate to a maximum the secretion of $\mathrm{K}^{+}(19)$. Under these circumstances the stimulus of quiet standing was ineffective in changing the rates of excretion of either of these ions, although sodium was retained. Administration of mercury, which inhibits renal tubular secretion of $\mathrm{K}^{+}$in dogs (23), blocked the increase in $\mathrm{K}^{+}$excretion which usually accompanied motionless standing, but did not prevent a rise in ammonium excretion and fall in urinary $\mathrm{pH}$. The possibility cannot be excluded that increased amounts of chloride and bicarbonate in the tubular urine contributed to and modified these results by permitting the reabsorption of $\mathrm{Na}^{+}$with a reabsorbable anion. The data are compatible, however, with the theory that the renal retention of sodium produced acutely by quiet standing is caused in part by increased tubular reabsorption of sodium from urine through a mechanism of ionic exchange with tubular cells for both potassium and hydrogen ions. This process, not ordinarily apparent, is unmasked during a sulfate diuresis by the obligatory excretion in the urine of a large number of negative sulfate ions which require neutralization.

\section{SUM MARY}

1. Quiet standing during the course of a sodium sulfate diuresis produced the following changes:

a. An abrupt decrease in the renal excretion of sodium and chloride.

b. Little change in urine flow, creatinine clearance, or the excretion of sulfate.

c. An increase in the excretion of potassium and ammonium and a fall in urinary $\mathrm{pH}$.

2. Administration of Diamox ${ }^{\circledR}$ prior to quiet standing prevented the increase in excretion of potassium and acid during quiet standing.

3. Administration of Thiomerin prior to quiet standing blocked the increase in potassium excretion but did not prevent the formation of a more acid urine with an increase in the excretion of ammonium.
4. The results suggest that under these circumstances both potassium and hydrogen ions may participate simultaneously in the reabsorption of sodium by the renal tubules through an active process of ionic exchange.

\section{ACKNOWLEDGMENT}

The authors acknowledge the technical assistance of Mrs. Eva Taborsky, Mrs. Gloria Hoffenberg, and Mrs. Marjorie Beach.

\section{REFERENCES}

1. Epstein, F. H., Goodyer, A. V. N., Lawrason, F. D., and Relman, A. S., Studies of the antidiuresis of quiet standing: The importance of changes in plasma volume and glomerular filtration rate. $\mathrm{J}$. Clin. Invest., 1951, 30, 63.

2. Wilkins, R. W., Tinsley, C. M., Culbertson, J. W., Burrows, B. A., Judson, W. E., and Burnett, C. H., The effects of venous congestion of the limbs upon renal clearances and the excretion of water and salt. I. Studies in normal subjects and in hypertensive patients before and after splanchnicectomy. J. Clin. Invest., 1953, 32, 1101.

3. Farber, S. J., Becker, W. H., and Eichna, L. W., Electrolyte and water excretions and renal hemodynamics during induced congestion of the superior and inferior vena cava of man. J. Clin. Invest., 1953, 32, 1145.

4. Goodyer, A. V. N., and Seldin, D. W., The effects of quiet standing on solute diuresis. J. Clin. Invest., 1953, 32, 242.

5. Berliner, R. W., Renal excretion of water, sodium, chloride, potassium, calcium and magnesium. Am. J. Med., 1950, 9, 541.

6. Lifson, N., and Visscher, M. B., Osmosis in living systems in Medical Physics, Glasser, Otto, Ed., Chicago, Yearbook Publishers, 1944, vol. 1, p. 876.

7. Hare, R. S., Endogenous creatinine in serum and urine. Proc. Soc. Exper. Biol. \& Med., 1950, 74, 148.

8. Hald, P. M., The flame photometer for the measurement of sodium and potassium in biological materials. J. Biol. Chem., 1947, 167, 499.

9. Hald, P. M. in Peters, J. P., and Van Slyke, D. D., Quantitative Clinical Chemistry, Vol. II, Methods, Baltimore, Williams and Wilkins, 1932, p. 838.

10. Harvey, S. C., The quantitative determination of the chlorids in the urine. Arch. Int. Med., 1910, 6, 12.

11. Van Slyke, D. D., and Neill, J. M. in Peters, J. P., and Van Slyke, D. D., Quantitative Clinical Chemistry, Vol. II, Methods, Baltimore, Williams and Wilkins, 1932, p. 285.

12. Nalefski, L. A., and Takano, F., A photonephelometric method for the determination of sulfates in biologic fluids. J. Lab. \& Clin. Med., 1950, 36, 468. 
13. Letonoff, T. V., and Reinhold, J. G., A colorimetric method for the determination of inorganic sulfate in serum and urine. J. Biol. Chem., 1936, 114, 147.

14. Kleeman, C. R., Taborsky, E., and Epstein, F. H., An improved method for the determination of inorganic sulfate. To be published.

15. Conway, E. J., Microdiffusion Analysis and Volumetric Error. London, Crosby Lockwood and Son, Ltd., 1947.

16. Pearce, M. L., and Simmons, D. H., Effects of water diuresis and postural and Pitressin antidiuresis on urine composition. Federation Proc., 1954, 13, 109.

17. Epstein, F. H., and Kleeman, C. R., Unpublished studies.

18. Lauson, H. D., and Thompson, D. D., Effects of decrease in glomerular filtration rate on cation excretion during loading with nonreabsorbable anions. Federation Proc., 1953, 12, 83.

19. Berliner, R. W., Kennedy, T. J., Jr., and Orloff, J., Relationship between acidification of the urine and potassium metabolism. Effect of carbonic anhy- drase inhibition on potassium excretion. Am. J. Med., 1951, 11, 274.

20. Schwartz, W. B., Jenson, R. L., and Relman, A. S., Acidification of the urine and increased ammonium excretion without change in acid-base equilibrium: sodium reabsorption as a stimulus to the acidifying process. J. Clin. Invest., 1955, 34, 673.

21. Ingbar, S. H., Kass, E. H., Burnett, C. H., Relman, A. S., Burrows, B. A., and Sisson, J. H., The effects of ACTH and cortisone on the renal tubular transport of uric acid, phosphorus, and electrolytes in patients with normal renal and adrenal function. J. Lab. \& Clin. Med., 1951, 38, 533.

22. Metcoff, J., James, J. A., Gordillo, G., and Antonowicz, I., Renal electrolyte transport in normal and nephrotic children. Effects of simultaneous infusion of carbonic anhydrase inhibitor and nonreabsorbable anion. J. Lab. \& Clin. Med, 1955, 46, 333.

23. Mudge, G. H., Ames, A., III, Foulks, J., and Gilman, A., Effect of drugs on renal secretion of potassium in the dog. Am. J. Physiol., 1950, 161, 151. 